\title{
Köln's unstable hemoglobin: case report and literature review
}

\author{
Hemoglobina instável de Köln: relato de caso e revisão de literatura
}

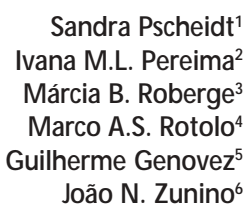

\begin{tabular}{l|l}
\multicolumn{1}{c|}{ key words } & a bstract \\
Hemoglobinopathies & $\begin{array}{l}\text { Unstable hemoglobins are a group of genetic variants of hemoglobins caused by the mutation of amino } \\
\text { acids into alpha and beta globins and, depending on the points and types of mutation, the result can } \\
\text { Unstable hemoglobin }\end{array}$ \\
$\begin{array}{l}\text { Köln HB } \\
\text { vary from no clinical symptomatology to severe hemolytic anemia. On the present report, we study the } \\
\text { case of a female patient who showed a very exuberant hematological picture for the red series, which } \\
\text { suggests hemoglobinic changes; this was confirmed following the conduction of the protocol established } \\
\text { by Laboratório Médico Santa Luzia for the study of hemoglobinopathies and which was then sent for a } \\
\text { reference laboratory: C.D.A. Naoun Laboratórios de Análises Clínicas }\end{array}$
\end{tabular}

resumo

As hemoglobinas instáveis constituem um grupo de variantes genéticas de hemoglobinas causadas pela mutação de aminoácidos nas globinas alfa e beta e, dependendo dos pontos e dos tipos de mutações ocorridos, o resultado pode ser de nenhuma sintomatologia clínica até anemias hemolíticas graves. No presente relato, estudamos o caso de uma paciente que apresentava um quadro hematológico de série vermelha bastante exuberante, sugestivo de alteração hemoglobínica, o que foi confirmado após realização do protocolo estabelecido pelo Laboratório Médico Santa Luzia para estudo de hemoglobinopatias e posteriormente enviado para o laboratório de referência C.D.A. Naoun Laboratórios de Análises Clínicas.

\section{Unitermos}

Hemoglobinopatias Hemoglobina instável

\section{Introduction}

Hemoglobinopathies affect millions of people throughout the world, determining clinical syndromes that depend on homozygotic and heterozygotic conditions or in association of two abnormal hemoglobins. The incidence is directly related to racial miscegenation.

The several types of hemoglobinopathy vary according to the different stages of human development. The functions of the hemoglobins are marked since the first days of pregnancy, adapting to the constant development of the embryo and the fetus until the stabilization, six months after birth (3).

Among known hemoglobinopathies, the unstable hemoglobins are a group of genetic variants of hemoglobins in which the mutation of amino acids into alpha and beta globins affect the structure of the molecule, making it unstable. The evaluation of the stability of the hemoglobin molecule is performed by physico-chemical methods that are currently wellestablished, among which we can highlight the heating of the hemolysate solution between $50^{\circ} \mathrm{C}$ and $60^{\circ} \mathrm{C}$, the incubation with isopropanol at $37^{\circ} \mathrm{C}$, or the vigorous stirring of the tube containing the hemolysate. Thus, the hemoglobins that precipitate faster than the normal ones are considered unstable (3).

Due to the great diversity of mutation points on the globinic structure, as well as the types of mutation by substitution or deletion of amino acids, the unstabilizing forms vary greatly. In this situation, some hemoglobins are discreetly unstable and are not
1. Coordenadora de estudos de hemoglobinopatia do Setor de Hematologia do Laboratório Médico Santa Luzia.

2. Coordenadora técnica de qualidade do Laboratório Médico Santa Luzia.

3. Chefe do Setor de Hematologia do Laboratório Médico Santa Luzia.

4. Consultor cientifico dos Setores de Hematologia e Citometria de Fluxo do Laboratório Médico Santa Luzia.

5. Consultor científico do Setor de Hematologia do Laboratório Médico Santa Luzia. 
associated to clinical symptoms, while other unstable hemoglobins precipitate with great intensity, causing hemolytic anemia, excretion of "free heme" such as dipyrroles, making the patient's urine dark (2). This type of anemia can be severe, with significant decrease of hemoglobin levels and very elevated reticulocytosis, or they can manifest with a modest hemolytic picture accompanied by a modest reticulocytosis (3).

One of the main characteristics of unstable hemoglobins which cause hemolytic anemia is the presence of Heinz bodies. The degree of instability is related to its production and to the severity of the anemia (3).

The case report diagnosed at Laboratório Médico Santa Luzia in Florianópolis, State of Santa Catarina, Brazil, describes an unstable hemoglobin known as Köln's unstable hemoglobin.

The history of Köln's hemoglobin starts with a small notification delivered at a Hemoglobin Colloquium in Vienna. Pribilla (1962) reported that an abnormal hemoglobin component had been found on a family from middle Reno, which suffered from a condition similar to thalassemia. They did not have family relations with Mediterranean, African or Asian people. This component, which in electrophoresis formed a smaller band between hemoglobin $A$ and hemoglobin $A_{2}$, and which comprised about $5 \%$ of total hemoglobin, appeared as a "new" hemoglobin and was called Köln's hemoglobin. A more detailed description of the case in this family was given by Pribilla and colleagues (1965) with the title Hämoglobin-Köln-Krankheit: familiäre hupocrome hämolytische anämie mit hämoglobinamalie. Of the nine cases found in four generations, five were confirmed and four remained inconclusive. The patients were moderately anemic: hemoglobin $10.5-13.5 \mathrm{~g} / \mathrm{dl}$, reticulocytes $190-270 \times 10^{9} / \mathrm{l}$, MCH 26-28pg, MCV 96-122fl, bilirubin 1.0-2.5mg/dl; there were anisocytosis and basophilic dots. The osmotic fragility were moderately reduced. All had splenomegaly. Physicochemical studies led to the conclusion that the abnormal hemoglobin was characterized as an abnormality in its bglobin chain between residues 83 and 120. It was later demonstrated by Carrell, Lehmann and Pribilla (1967), in Cambridge, that the German Köln's hemoglobin had the same abnormality (methionine instead of valine in position $b$ 98) as had been previously found in two families in Great Britain (1).

In Brazil, the development of unstable hemoglobins is not uncommon. Several cases have been reported in the States of São Paulo, Rio Grande do Sul, Rio de Janeiro, Santa Catarina and Amazonas (3).

\section{Case report}

A female patient, white, 23 years old, was admitted into the hospital on the second semester of 2000; she had been run over by a car and had a fracture on the left tibia. During the clinical investigation, the patient reported that, when she was 6 , she had undergone a splenectomy and, at 11 , she had been cholecystectomized, and that she had alpha thalassemia. Upon this hospitalization, the laboratory values of the hemogram revealed a marked anemia: hematocrit 24.4\%, hemoglobin 7.7g/dl, MCV 124fl, MCH $39.9 \mathrm{pg}$. There were anisocytosis, poikilocytosis, polychromasia, macrocytosis, basophilic dots, erythrocytes in target and spherocytes (Figure 1).

Because of the strong anemia with signs of diserythropoiesis, the patient was forwarded to a hematologist, who requested a hemoglobin electrophoresis and reticulocytes count. On the electrophoresis conducted with agarose gel in alkaline $\mathrm{pH}$, an anomalous fraction between hemoglobins $A_{1}$ and $A_{2}$ was observed. The protocol from Laboratório Médico Santa Luzia instructs that when anomalous fractions are present, a hemoglobin electrophoresis must be enhanced for a hemoglobinopathy study composed of the following tests: reticulocyte count, investigation of Heinz bodies, investigation of $\mathrm{H}$ bodies, fetal hemoglobin dose, falcization test, thermoinstability test and osmotic resistance test. In the case reported, methemoglobin dose was also included.

With the altered results and the suspicion of unstable hemoglobin, a new sample was requested, which was forwarded to the reference laboratory in hemoglobinopathies: C.D.A. Naoun Laboratórios de Análises Clínicas, in São José do Rio Preto, State of São Paulo. The purpose of this was to confirm and classify the unstable hemoglobin under study.

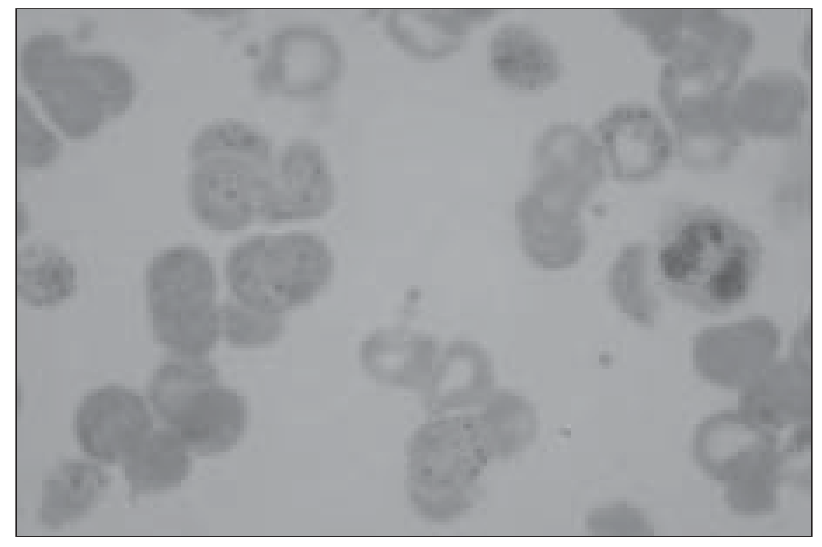

Figure 1 - Blood smear of peripheral blood. Source: LMSL 


\section{Discussion}

The main laboratory evidence of unstable hemoglobins is their reduced stability when submitted to heat from $50^{\circ} \mathrm{C}$ to $60^{\circ} \mathrm{C}$. Particularly, any change that reduces the contacts between the sub-units that compose the hemoglobin will generate its instability. Important examples are hemoglobins $E$ and $S$, which give slightly positive reactions when submitted to heat tests and to isopropanol. Even though these hemoglobins have a slight degree of instability, the term unstable hemoglobins must only be used for those hemoglobins that produce Heinz inclusion bodies in patients with acute or chronic hemolytic anemia (3).

The data obtained at Laboratório Médico Santa Luzia (LMSL) and C.D.A. Naoun Laboratórios de Análises Clínicas (CDA Naoun) are represented in the Table.

The results obtained in both laboratories are equivalent. Of the tests conducted at the LMSL, the investigation for Heinz bodies (Figure 2), the thermoinstability and the methemoglobin were compatible with unstable hemoglobin.

The hemoglobin electrophoresis with saponin conducted at CDA Naoun confirmed the presence of an unstable hemoglobin classified as Köln. The fraction located on the position of hemoglobin S is Köln's hemoglobin, and the fraction behind the application point is due to free alpha globin chains, since Köln's hemoglobin is a mutant of the beta globin that separates from alpha globin (Figure 3).
The tests conducted in both laboratories, Laboratório Médico Santa Luzia and C.D.A. Naoun Laboratórios de Análises Clínicas, are mutually compatible and confirm the suspicion of Köln's unstable hemoglobin.

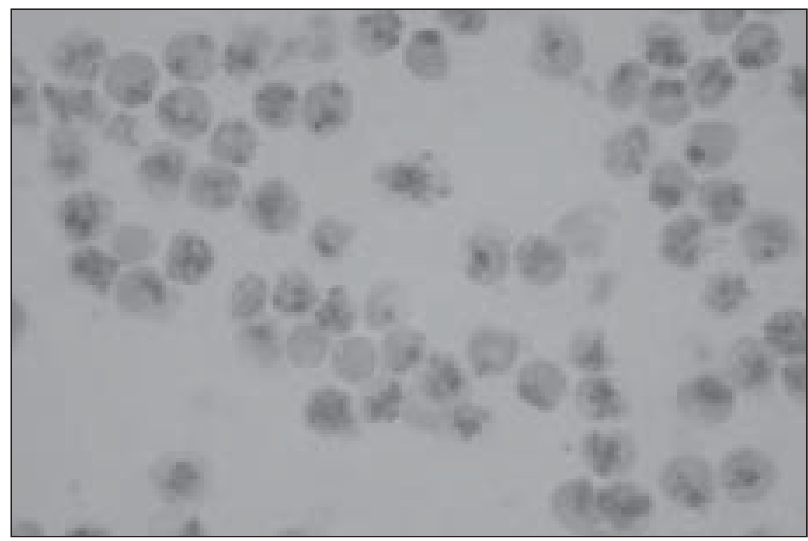

Figure 2 - Erythrocytes with precipitates of Heinz bodies. Source: LMSL

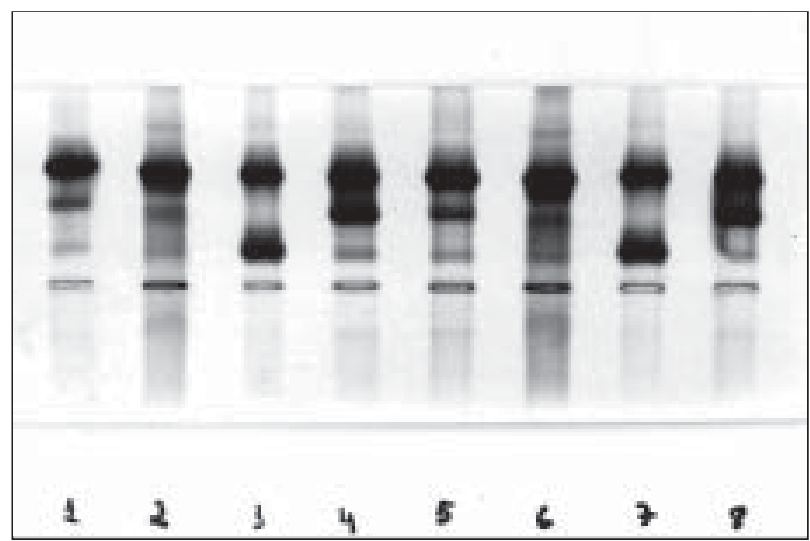

Figure 3 - Hemoglobin electrophoresis: 1 and 5: $\mathrm{Hb} \mathrm{A}+$ Lepore; 3 and 7: $\mathrm{Hb} \mathrm{AC;} 4$ and 8: $\mathrm{Hb} A S ; 2$ and 6: unstable Hb. Source: C.D.A. Naoun Laboratórios de Análises Clínicas

\section{Table}

Parameter

Reticulocyte count (\%)

Heinz bodies

$\mathrm{H}$ bodies

Fetal hemoglobin (\%)

Falcization test

Thermoinstability test

Osmotic resistance test

Hemoglobin A1 (\%)

Hemoglobin A2 (\%)

Unstable hemoglobin

Methemoglobin (\%)

\section{LMSL}

25.6

Present

Absent

4.5

Negative

Positive

Positive

95.7

4.3

Present
CDA Naoun

Present

Absent

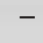

Positive

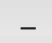

3.6

Present (Köln)

10 


\section{References}

1. D acie, J.V. The haemolytic anaemias. $3^{\text {rd }}$ ed. N ew York: C hurchill Livingstone, 1988. 5v. v. 2: The hereditary haemolytic anaemias part 2. p. 326-327.

2.Lehmann, H.\& H untsman, R.G .M an's haemoglobins. Amsterdam: N orth Holland Publishing Company, 1974. p. 221.
3. N aoun, P.C .H emoglobinopatias e talassemias. São Paulo: Sarvier, 1977. p. 73-4.

4. Lee, G.R. et al. W introbe's clinical hematology. $10^{\text {th }}$ ed. Baltimore: W illiams \& W ilkings, 1999. v. l, p.1938-404.

5.Bain,B.J.Blood cells:A practical guide.London:Lippincott, 1989. p. 274 